\title{
Kajian Yuridis Penyelesaian Perselisihan Hasil Pemilihan Kepala Desa
}

\section{Supriyadi}

Supriyadi; Fakultas Hukum Universitas Merdeka Malang; Jl. Terusan Raya Dieng No. 62-64; Malang; Indonesia.

\section{ARTICLEINFO}

\section{Article history:}

Received 2019-06-29

Received in revised form

2019-09-19

Accepted 2019-12-01

\section{Kata kunci:}

Pemilihan Kepala Desa;

Perselisihan Hasil;

Penyelesaian.

\section{Keywords:}

Headman Election; Headman Election Result Disputes; Solution.

DOI: https://doi.org/10.26905/ idjch.v10i2.3541.

\begin{abstract}
Abstrak
Pemilihan kepala desa merupakan bagian dari sistem penyelenggaraan pemerintahan desa yang transparan, mandiri, akuntabel, dan demokratis. Pelaksanaan pemilihan kepala desa yang dilaksanakan secara langsung, umum, bebas, rahasia, jujur, dan adil diharapkan dapat menghasilkan seorang kepala desa yang mampu memimpin dan menyelenggarakan pemerintahan desa secara efektif, efisien, bertanggungjawab, dan dipercaya oleh masyarakat guna mencapai kemajuan dan mewujudkan kesejahteraan masyarakat desa. Dari kajian yuridis terhadap peraturan perundangundangan yang mengatur secara langsung tentang pemilihan kepala desa tidak cukup memadai ketentuan yang berkenaan dengan perselisihan hasil pemilihan kepala desa, kecuali hanya menentukan bupati/walikota sebagai pihak yang wajib menyelesaikan perselisihan dalam waktu 30 (tiga puluh) hari, dan batas waktu 3 (tiga) hari untuk mengajukan keberatan. Oleh karena itu, pengaturan lebih teknis mengenai tahapan, mekanisme, dan prosedur penyelesaian perselisihan pemilihan kepala desa ke dalam produk hukum Daerah akan sangat membantu memberikan jalan keluar bagi panitia pelaksana pemilihan baik di tingkat desa maupun kabupaten/kota, para calon kepala desa, masyarakat desa, dan bupati/walikota yang diberi kewajiban menyelesaikan perselisihan hasil pemilihan kepala desa.
\end{abstract}

\section{Abstract}

Headman election are part of a village government implementation system that transparent, independent, accountable and democratic. Conducting headman election in direct, general, free, confidental, honest and fair are expected to produce a headman who is able to lead and organize village government in effective, efficient, responsible manner, and trusted by the villagers. This kind of headman can create and increase the welfare of the villagers. Based on juridical study, the legislation that directly regulates headman election is not adequate enough for the provision concerning dispute of headman election result. It only appoint regent/mayor as a party that obligated to settle disputes within 30 (thirty) days, and a deadline to

Corresponding Author:

* Supriyadi.

E-mail address: supriyadi@unmer.ac.id 
submit an objection is 3 (three) days. Therefore, making a more technical regulationregarding the stages, mechanisms, and procedures for resolving headman election disputes in a form of regional legal products will greatly help providing a solution for the election implementation committee at both the village and regency/ city level, candidates for headman, villagers, and regent/mayor who was given the obligation to resolve dispute of headman election result.

\section{Latar Belakang}

Pengertian Pilkades baru ditemukan dalam Peraturan Menteri Dalam Negeri Nomor 112 Tahun 2014 (Permendagri No. 112 Th. 2014) tentang Pemilihan Kepala Desa sebagai tindak lanjut dari PP No. 43 Th. 2014, dirumuskan bahwa pemilihan kepala desa adalah "pelaksanaan kedaulatan rakyat di desa dalam rangka memilih kepala desa yang bersifat langsung, umum, bebas, rahasia, jujur, dan adil" (Pasal 1 butir 5).

Sebagai perbandingan, untuk pengisian jabatan publik melalui pemilihan pada level di atasnya, seperti gubernur, bupati/walikota, dalam Undang-Undang Nomor 1 Tahun 2015 tentang Penetapan Peraturan Pemerintah Pengganti Undang-Undang Nomor 1 Tahun 2014 tentang Pemilihan Gubernur, Bupati, dan Walikota Menjadi Undang-Undang, sebagaimana diubah dengan Undang-Undang Nomor 8 Tahun 2015 dan terakhir dengan Undang-Undang Nomor 10 Tahun 2016 dirumuskan bahwa pemilihan gubernur dan wakil gubernur, bupati dan wakil bupati, serta walikota dan wakil walikota yang selanjutnya disebut pemilihan adalah "pelaksanaan kedaulatan rakyat di wilayah provinsi dan kabupaten/kota untuk memilih gubernur dan wakil gubernur, bupati dan wakil bupati, serta walikota dan wakil walikota secara langsung dan demokratis" (Pasal 1 butir 1). Sedangkan dalam Pasal 2 dirumuskan bahwa pemilihan dilaksanakan secara demokratis berdasarkan asas langsung, umum, bebas, rahasia, jujur, dan adil.
Sementara itu, untuk pengisian jabatan publik lainnya melalui pemilihan umum, dalam Pasal 1 butir 1 Undang-Undang Nomor 7 Tahun 2017 tentang Pemilihan Umum, dirumuskan bahwa pemilihan umum adalah "sarana kedaulatan rakyat untuk memilih anggota Dewan Perwakilan Rakyat (DPR), anggota Dewan perwakilan Daerah (DPD), Presiden dan Wakil presiden, dan untuk memilih anggota Dewan Perwakilan Rakyat Daerah (DPRD), yang dilaksanakan secara langsung, umum, bebas, rahasia, jujur, dan adil dalam Negara Kesatuan Republik Indonesia berdasarkan Pancasila dan Undang-Undang Dasar Negara Republik Indonesia Tahun 1945".

Jika dicermati pengertian pemilihan kepala desa secara yuridis, linier dengan pengertian pemilihan kepala daerah (gubernur, bupati/walikota), bahkan pemilihan umum pada umumnya untuk memilih anggota DPR, anggota DPD, Presiden dan Wakil Presiden, dan anggota DPRD, yaitu mengandung 3 (tiga) unsur: pertama, sebagai sarana atau pelaksanaan kedaulatan rakyat; kedua, jabatan yang hendak diisi (kepala desa, kepala daerah, Presiden dan Wakil Presiden, serta anggota DPR, DPD, dan DPRD); dan ketiga, prinsip yang menjadi dasar pelaksanaan: LUBER dan Jurdil (langsung, umum, bebas, rahasia, jujur, dan adil).

Dengan demikian, pemilihan untuk mengisi jabatan apapun mempunyai kesamaan, yang membedakan terletak pada kedudukan atau posisi dan lingkup jabatan yang hendak diisi, yang mungkin berakibat pada kompleksitas persoalan, sehingga 


\section{Jurnal Cakrawala Hukum, Volume 10 No. 2 Desember 2019}

ISSN PRINT 2356-4962 ISSN ONLINE 2598-6538

munculnya permasalahan dalam pelaksanaan pemilihan untuk mengisi jabatan apapun semua bisa terjadi pada level manapun.

\section{Metode}

Penelitian ini menggunakan penelitian normatif empiris yang dilakukan untuk menelaah kaidah hukum normatif yang dilihat dari segi penerapannya, serta untuk mencermati bagaimana penyelesaian perselisihan hasil pemilihan kepala desa, serta apakah cukup memadai dasar hukum dalam menyelesaikan perselisihan hasil pemilihan kepala desa. Dengan pendekatan yuridis-empiris, pendekatan yuridis karena berpijak pada ketentuan-ketentuan hukum sebagai dasar normatif, sedangkan pendekatan empiris, karena dalam penelitian ini melakukan peninjauan pelaksanaan ketentuan yuridis tersebut, termasuk mengkaji halhal yang berpengaruh pada pelaksanaan ketentuan hukum yang berlaku di masyarakat di telah dari sisi implementasinya.

\section{Pembahasan}

\subsection{Landasan Hukum Penyelesaian Perselisihan Hasil Tidak Memadai}

Ketentuan yang mengatur masalah pemilihan kepala desa, khususnya yang menyangkut penyelesaian terhadap pelanggaran relatif tidak ada pengaturan sama sekali baik yang berkenaan dengan "proses" penyelenggaraan maupun yang berkenaan dengan "hasil", sehingga bisa dipastikan ketika terjadi pelanggaran dalam penyelenggaraan pemilihan kepala desa, tidak ada landasan hukum yang bisa dipakai sebagai rujukan dan hampir bisa dipastikan penyelesaiaannya pun selain beragam tidak standar juga sulit untuk memenuhi rasa keadilan bagi para pihak yang berselisih atau yang bersengketa. Padahal salah satu nilai yang mendasari demokrasi adalah menyelesaikan perselisihan dengan damai dan sukarela (Henry B. Mayo, dalam Hendra Nurtjahjo, 2005), dan hal tersebut dapat terwujud jika pegaturan masalah penyelesaian perselisihan yang terkait baik proses maupun hasil pemilihan diatur secara lengkap, transparan, dan obyektif.

Dalam UU No. 6 Th. 2014, Pasal 37 ayat (6) hanya menentukan "dalam hal terjadi perselisihan hasil pemilihan Kepala Desa, Bupati/Walikota wajib menyelesaikan perselisihan dalam jangka waktu sebagaimana dimaksud pada ayat (5)", sementara pada ayat (5) Pasal 37 tersebut menentukan waktu paling lama 30 (tiga puluh) hari sejak tanggal diterimanya penyampaian hasil pemilihan dari panitia pemilihan Kepala Desa. Jadi Pasal 37 ayat (5) dan ayat (6) UU No. 6 Th. 2014 hanya menentukan siapa yang berwenang, yaitu Bupati/Walikota dan jangka waktu yang dialokasikan, yaitu 30 (tiga puluh) hari untuk menyelesaikan perselisihan hasil Pilkades, sedangkan bagaimana tata cara, prosedur, dan mekanismenya yang berkaitan dengan penyelesaiannya hasil pemilihan kepada desa tidak diatur sama sekali.

Begitu pula PP No. 43 Th. 2014 Junto PP No. 47 Th. 2015 sebagai tindak lanjut dari UU No. 6 Th. 2014 juga tidak mengatur masalah penyelesaian perselisihan hasil Pilkades. Dalam Peraturan Pemerintah ini hanya ada 7 (tujuh) pasal, yaitu: Pasal 40 sampai dengan Pasal 46 yang mengatur malasah tata cara pemilihan kepala desa dan hanya 1 (satu) ayat, yaitu ayat (7) dalam Pasal 41 yang isinya sama dengan Pasal 37 ayat (6) UU No. 6 Th. 2014, yaitu: "dalam hal terjadi perselisihan hasil pemilihan kepala Desa, bupati/walikota wajib menyelesaikan perselisihan dalam jangka waktu 30 (tiga puluh) hari".

Sebagai tindak lanjut dari PP No. 43 Th. 2014, Menteri Dalam Negeri mengeluarkan Permendagri No. 112 Th. 2014 yang diubah dengan Permendagri No. 65 Th. 2017. Permendagri ini dikeluarkan khusus untuk mengatur masalah pemilihan kepala desa, tetapi sangat disayangkan dari 50 (lima puluh) pasal yang terdapat dalam Peraturan Menteri Dalam Negeri ini justru tidak disinggung sedikit pun tentang persoalan penyelesaian perselisihan hasil 
Pilkades, apalagi solusi terhadap pelanggaran proses pelaksanaan Pilkades. Kalau pun ada ketentuan yang menyinggung persoalan penyelesaian yang terkait dengan pelaksanaan pemilihan kepala desa secara garis besar, itu pun sangat sumir seperti yang diatur dalam Pasal 5 ayat (2) huruf f Permendagri No. 112 Th. 2014 sebagai salah satu tugas Panitia Pilkades tingkat kabupaten/kota yang menentukan bahwa "panitia pemilihan di Kabupaten/ Kota mempunyai tugas diantaranya adalah memfasilitasi penyelesaian permasalahan pemilihan kepala desa tingkat kabupaten/kota". Tentu, ketentuan tersebut masih sangat kabur apa yang dimaksud dengan "memfasilitasi penyelesaian permasalahan pemilihan kepala desa tingkat kabupaten/kota".

Apakah penyelesaian permasalahan Pilkades tersebut terkait dengan proses dan sekaligus sampai hasil pemilihan kepala desa, hal ini menjadi pertanyaan besar. Yang sudah pasti tugas memfasilitasi cenderung lebih pada membantu mencarikan jalan keluar, menjadi mediator bagi para pihak jika terjadi permasalahan yang terkait dengan pemilihan kepala desa, tetapi bukan sebagai pemutus atas perselisihan yang timbul terkait pelaksanaan pemilihan kepala desa. Meskipun demikian, jika fungsi tersebut dapat dilaksanakan secara maksimal, setidak-tidaknya akan dapat mengurangi konflik yang terkait dengan pelaksanaan pemilihan kepala desa. Hal ini sejalan dengan fungsi aparatur pemerintah (Daerah) sebagai agent of mediation and resolution dalam penyelesaian masalah hukum (Jimly Asshiddiqie, 2006).

3 (tiga) produk hukum yang dikeluarkan di tingkat Pusat, yaitu: UU No. 6 Th. 2014, PP No. 43 Th. 2014 yang diubah dengan PP No. 47 Th. 2015, dan Permendagri No. 112 Th. 2014 yang diubah dengan Permendagri No. 65 Th. 2017, hampir bisa dikatakan tidak cukup mengatur persoalan yang terkait dengan perselisihan hasil pemilihan kepala desa, apalagi jika dikaitkan dengan pelanggaran proses pelaksanaan pemilihan kepala desa, kecuali untuk 3 (tiga) hal saja, yaitu: "kewajiban" bupati/ walikota untuk menyelesaikan perselisihan hasil pemilihan kepala desa, "jangka waktu" 30 (tiga puluh) hari untuk menyelesaikannya, dan fasilitasi penyelesaian permasalahan Pilkades tingkat kabupaten/kota oleh Panitia Pilkades tingkat kabupaten/kota.

\subsection{Produk Hukum Daerah Juga Tidak Mengatur Teknis Penyelesaian Hasil}

Permendagri No. 112 Th. 2014, pemberian kewenangan sub delegasi kepada Daerah Kabupaten/Kota untuk melakukan pengaturan lebih lanjut atas pemilihan kepala desa hanya dibatasi pada masalah yang terkait dengan persyaratan tambahan untuk mendaftar sebagai calon kepala desa yang bisa diatur ke dalan peraturan daerah (Perda) sebagaimana ditentukan dalam Pasal 21 huruf $m$ dan perihal yang terkait dengan masalah kelengkapan Pilkades yang diatur lebih lanjut dalam Peraturan Bupati/Walikota, sebagaimana ditentukan dalam Pasal 34.

Sebagai salah satu untuk mengetahui pengaturan lebih lanjut pemilihan kepala desa yang dikeluarkan di tingkat Daerah baik dalam bentuk peraturan daerah maupun peraturan bupati, khususnya untuk melihat apakah dalam produk hukum Daerah tersebut juga melakukan pengaturan hal-hal yang terkait dengan penyelesaian perselisihan hasil pemilihan kepala desa, di bawah ini disajikan Peraturan Daerah Kabupaten Malang Nomor 1 Tahun 2016 tentang Desa, dan Peraturan Bupati Malang Nomor 21 Tahun 2018 tentang Pemilihan Kepala Desa sebagaimana diubah dengan Peraturan Bupati Malang Nomor 5 Tahun 2019.

Perda Kabupaten Malang No. 1 Th. 2016 terdapat 268 pasal, perihal yang terkait dengan pemilihan kepala desa di atur ke dalam 53 (lima puluh tiga) pasal, yaitu dari Pasal 76 sampai dengan Pasal 128. Dari 53 (lima puluh tiga) pasal tersebut, tidak satu pun pasal atau ayat yang menyinggung persoalan penyelesaian perselisihan 


\section{Jurnal Cakrawala Hukum, Volume 10 No. 2 Desember 2019}

ISSN PRINT 2356-4962 ISSN ONLINE 2598-6538

hasil pemilihan kepala desa. Sementara itu, peraturan yang lebih operasional dan teknis di tingkat Daerah (Kabupaten Malang) yang khusus mengatur masalah pemilian kepala desa diatur dalam Perbup Malang No. 21 Th. 2018 sebagaimana diubah dengan Perbup Malang No. 5 Th. 2019. Dalam Peraturan Bupati ini terdapat 68 pasal, perihal yang terkait dengan penyelesaian perselisihan hasil pemilihan kepala desa hanya di atur ke dalam 1 (satu) pasal, yaitu Pasal 54 yang ditempatkan dalam Bab II Bagian Keempatbelas. Pasal 54 Peraturan Bupati Malang Nomor 21 Tahun 2018 ini terdiri atas 3 (tiga) ayat yang secara substansi tidak jauh berbeda dengan apa yang sudah diatur dalam Pasal 37 ayat (5) dan ayat (6) UU No. 6 Th. 2014 yang diulang dalam ayat (7) Pasal 41 PP No. 43 Th. 2014 yang pada intinya hanya menentukan siapa yang berwenang, yaitu Bupati/Walikota dan jangka waktu yang dialokasikan, yaitu 30 (tiga puluh) hari.

Perselisihan hasil pemilihan kepala desa, hanya dalam Pasal 54 Peraturan Bupati Malang Nomor 21 Tahun 2018 ini ditambahkan waktu pengajuan permohonan dibatasi paling lama 3 (tiga) hari setelah penetapan hasil penghitungan suara, selebihnya tidak ada pengaturan yang mengatur tentang bagaimana tata cara dan mekanisme serta kekuatan hukum dari penyelesaian perselisihan hasil pemilihan kepala desa, sehingga wajar jika permasalahan yang terkait dengan penyelesaian perselisihan pemilihan kepala desa ini menjadi gelap gulita tanpa landasan hukum yang jelas dan pasti, bisa diduga banyak persoalan yang terkait dengan masalah pemilihan kepala desa ini tidak terselesaikan dengan tuntas dan baik, ujung-ujungnya ada pihak-pihak baik yang terkait langsung dengan Pilkades, seperti calon kepala desa maupun masyarakat yang berkepentingan dengan penyelenggaraan pemilihan kepala desa ini tidak memperoleh penyelesaian dengan baik, jujur, adil, dan transparan. Padahal hakekat demokrasi salah satunya diwujudkan dengan cara terpilihnya pemimpin atau pembuat keputusan oleh para pemilih dengan pemilihan yang dilakukan secara jujur, adil, ber- kala, dan kompetitif (Samuel Huntington dalam Hendra Nurtjahjo, 2005).

Penyelenggaraan pemilihan kepala desa serentak di Kabupaten Malang gelombang ketiga yang diselenggarakan pada tanggal 30 Juni 2019 terdapat 269 desa yang menggelar pemilihan kepala desa, dan setidaknya terdapat 9 (sembilan) desa yang mengajukan keberatan atas hasil pemilihan, 2 (dua) diantaranya adalah Desa Jambearjo, Kecamatan Tajinan, dan Desa Pandesari, Kecamatan Pujon. Keberatan yang diajukan oleh kedua desa tersebut hampir sama, mulai dari proses pelaksanaan pemilihan yang dinilai tidak memenuhi asas Luber dan Jurdil sampai dengan penyelesaian hasil pemilihan kepala desa.

Landasan hukum untuk penyelesaian perselisihan hasil pemilihan kepala desa, apalagi yang terkait dengan proses pelaksanaan yang dapat berakibat terhadap hasil, ketentuan yang ada mulai dari UU No. 6 Th. 2014, PP No. 43 Th. 2014 yang diubah dengan PP No. 47 Th. 2015, Permendagri No. 112 Th. 2014 yang diubah dengan Permendagri No. 65 Th. 2017, Perda Kabupaten Malang No. 1 Th. 2016, dan Perbup Malang No. 21 Th. 2018 yang diubah dengan Perbup Malang No. 5 Th. 2019 tidak memadai sebagai landasan hukum penyelesaian masalah pemilihan kepala desa, meskipun dalam ketentuan tersebut secara tegas dinyatakan jika terjadi perselisihan hasil pemilihan kepala Desa, bupati/walikota wajib menyelesaikan perselisihan dalam jangka waktu 30 (tiga puluh) hari.

Namun kenyataannya, karena tidak jelasnya mekanisme dan prosedur penyelesaian perselisihan hasil pemilihan kepala desa, apalagi terkait dengan proses pelaksanaan pemilihan kepala desa, baik Panitia Pilkades di tingkat desa yang dibentuk oleh BPD (Badan Permusyawaratan Desa) maupun Panitia Pilkades Tingkat Kabupaten yang dibentuk oleh Bupati tidak mampu memberikan solusi ketika terjadi permasalahan baik yang terkait dengan proses maupun hasil. Bahkan Panitia Pemilihan Kepala Desa Tingkat Kabupaten (Malang) seperti 
dilansir Tribunjatim.com, sebagaimana tugas yang dibebankan kepada panitia berdasarkan Pasal 5 ayat (2) huruf f Permendagri No. 112 Th. 2014 melakukan fasilitasi penyelesaian permasalahan pemilihan kepala desa tingkat kabupaten dalam bentuk memberikan jawaban atas permohonan pengaduan atau keberatan yang disampaikan oleh calon kepala desa yang tidak menerima hasil pemilihan kepala desa (https:/jatim.tribunnews.com/2019/08/12/), bukan dalam bentuk adjudikasi (William C. Burton, 1992), sebagai salah satu cara pengambilan keputusan pihak yang berwenang setelah memberikan kesempatan kepada para pihak menyampaikan argumentasi dan bukti-bukti sebagai alat pendukungnya.

\subsection{Penyelesaian Pelanggaran Proses Pelaksana- an Tidak Operasional}

Penyelesaian permasalahan Pilkades di tingkat kabupaten/kota, bisa dilakukan oleh panitia pemilihan kepala desa tingkat kabupaten/kota, sebagaimana diatur dalam Pasal 5 ayat (2) huruf f Permendagri No. 112 Th. 2014 yang diatur ulang dalam Pasal 4 ayat (1) huruf e Peraturan Bupati Malang Nomor 5 Tahun 2019. Namun demikian, ketentuan tersebut masih memberikan dasar kewenangan yang dapat dilakukan oleh panitia pemilihan kepala desa tingkat kabupaten/kota, tetapi mekanisme dan tata cara penyelesaiannya seharusnya perlu ada pengaturan lanjutan, jika tidak, sama saja akan menemui ketidakjelasan dalam penyelesaian permasalahan terkait dengan proses pemilihan kepala desa.

Secara materiil, pada tahap pencalonan juga diatur dalam Permendagri No. 112 Th. 2014, khususnya Pasal 30 ayat (1) yang ditingkat Daerah Kabupaten Malang juga diatur ulang dalam Pasal 35 ayat (1) Perbup Malang No. 21 Th. 2018 yang mengatur larangan pelaksanaan kampanye terhadap hal-hal yang terkait dengan masalah dasar negara, keutuhan NKRI, penghinaan, masalah SARA, adu domba, kekerasan, perusakan, peng- gunaan fasilitas milik pemerintah, pendidikan, tempat ibadah, atribut calon lain, dan politik uang. Sedangkan pada ayat (2)-nya ditentukan bahwa dalam kegiatan Kampanye dilarang mengikutsertakan: kepala desa, perangkat desa, dan anggota badan permusyaratan desa.

Pelanggaran atas larangan dalam Pasal 30 ayat (1) Permendagri No. 112 Th. 2014 dikenakan sanksi sebagaimana ditentukan dalam Pasal 31 yang pararel dengan Pasal 36 ayat (1) Peraturan Bupati Malang Nomor 5 Tahun 2019, yaitu berupa peringatan tertulis atas pelanggaran larangan kampanye meskipun belum ada gangguan, dan dihentikan jika berdampak pada gangguan keaman- an, apalagi punya potensi menyebar ke tempat lain.

Sanksi yang ditentukan dalam Pasal 31 tersebut dirumuskan secara general, tidak memperhatikan tingkat pelanggaran terhadap ruang lingkup materi kampanye dan sayangnya dalam Permendagri No. 112 Th. 2014 ini tidak diatur secara tegas siapa yang berwenang untuk menyelesaikan jika terjadi pelanggaran terhadap larangan materi pelaksanaan kampanye tersebut, namun dalam Pasal 36 ayat (2) Peraturan Bupati Malang Nomor 5 Tahun 2019 di tentukan bahwa yang memberikan sanksi berupa peringatan tertulis dan penghentian kegiatan Kampanye adalah panitia pemilihan kepala desa tingkat desa.

Di tingkat Daerah, seperti Kabupaten Malang, selain pembentukan Panitia Pilkades tingkat desa dan Panitia Pilkades tingkat kabupaten, juga dibentuk desk pemilihan kepala desa di setiap/tingkat kecamatan. Desk pemilihan kepala desa ini sebagaimana ditentukan dalam Pasal 5 ayat (5) Peraturan Bupati Malang Nomor 5 Tahun 2019 mempunyai tugas membantu pelaksanaan Pilkades, fungsi koordinasi, inventarisasi masalah yang timbul, saran penyelesaian masalah Pilkades.

Salah satu tugas desk pemilihan kepala desa tersebut adalah menginventarisasi dan mengantisipasi permasalahan dan memberikan saran dan masukan terkait penyelesaian permasalahan pemilihan 


\section{Jurnal Cakrawala Hukum, Volume 10 No. 2 Desember 2019}

ISSN PRINT 2356-4962 ISSN ONLINE 2598-6538

Kepala Desa. Seperti halnya ketentuan-ketentuan yang dirumuskan secara umum, implementasi ketentuan tersebut diserahkan pelaksanaannya kepada masing-masing petugas yang ada di lapangan dan hampir bisa dipastikan penyelesaian permasalahan terkait dengan pemilihan kepala desa selain tidak terukur, juga banyak menimbulkan penyelesaian yang tidak tuntas, bahkan tidak menutup kemungkinan timbulnya masalah baru, bukan menyelesaikan masalah tanpa masalah.

Tahap pemungutan suara dan penghitungan suara di TPS (tempat pemungutan suara), untuk mengawal kegiatan panitia pemilihan kepala desa tingkat desa, dapat dihadiri dan disaksikan oleh saksi dari calon, BPD, pengawas, dan warga masyarakat, sebagaimana ditentukan dalam Pasal 38 dan Pasal 41 Peraturan Menteri Dalam Negeri Nomor 112 Tahun 2014. Yang menarik adalah di tingkat Daerah Kabupaten Malang, berdasarkan Pasal 48 ayat (2) Peraturan Bupati Malang Nomor 21 Tahun 2018 ditentukan bahawa "kegiatan pelaksanaan pemungutan suara dapat dihadiri oleh saksi dari Calon Kepala Desa, BPD, dan warga masyarakat", tanpa menyertakan "pengawas" yang dalam Pasal 38 Peraturan Menteri Dalam Negeri Nomor 112 Tahun 2014 justru diberikan kesempatan bagi pengawas (meskipun tidak ditentukan subyeknya) untuk ikut melakukan pengawasan jalannya pemungutan suara pemilihan kepala desa.

Meskipun tidak secara tegas ditentukan tentang lembaga yang berwenang untuk melakukan pengawasan, seperti Bawaslu, Bawaslu provinsi, Bawaslu kabupaten/kota, Panwaslu kecamatan, Panwaslu keluarahan/desa, dan pengawas TPS untuk penyelenggaraan pemilihan umum (memilih Presiden dan Wakil Presiden, anggota DPR, DPD, dan anggota DPRD provinsi dan DPRD kabuoaten/kota) dan pemilihan kepala daerah (untuk memilih gubernur, bupati/walikota), tetapi dalam Pasal 5 ayat (2) huruf g Peraturan Menteri Dalam Negeri Nomor 65 Tahun 2017 dan di Kabupaten Malang kemudian diatur ulang dalam Pasal 4 ayat (1) huruf f Per- aturan Bupati Malang Nomor 5 Tahun 2019 dinyatakan bahwa "salah satu tugas dan kewenangan panitia pemilihan kepala desa tingkat kabupaten adalah melakukan pengawasan penyelenggaraan pemilihan Kepala Desa dan melaporkan serta membuat rekomendasi kepada Bupati". Meskipun ketentuan semacam ini tentu masih sangat umum untuk dipakai sebagai landasan dalam pelaksanaan proses pemilihan kepala desa.

Tugas yang dibebankan kepada panitia pemilihan kepala desa tingkat desa, diantara 12 (dua belas) tugas sebagaimana diatur dalam Pasal 9 Permendagri No. 112 Th. 2014 dan di Kabupaten Malang kemudian diatur ulang dalam Pasal 6 ayat (7) Peraturan Bupati Malang Nomor 21 Tahun 2018 adalah merencanakan, mengoordinasikan, menyelenggarakan, mengawasi dan mengendalikan semua tahapan pelaksanaan Pemilihan Kepala Desa. Lazimnya tugas mengawasi terhadap tahapan pelaksanaan pemilihan ditangani oleh lembaga atau bagian yang juga independen atas penyelenggaraan pemilihan (Hans Kelsen, 1973), dalam hal ini lembaga atau bagian atau panitia di luar panitia Pilkades, karena panitia pemilihan ini diberikan kewenangan untuk menyelenggarakan atau melaksanakan pemilihan kepala desa yang tidak menutup kemungkinan juga bisa dimasalahkan oleh calon kepala desa yang merasa diperlakukan tidak adil, sehingga fungsi pengawasan tidak dilekatkan jadi satu dengan panitia pemilihan yang menyelenggarakan pemilihan kepala desa.

\subsection{Penyelesaian Perselisihan Hasil Pemilihan Kepala Desa}

Pengaturan penyelesaian perselisihan pemilihan kepala desa ke dalam peraturan daerah kabupaten/kota telah memperoleh pijakan hukum berdasarkan Pasal 31 UU No. 6 Th. 2014, apalagi jika dikaitkan dengan ketentuan Pasal 37 ayat (6) yang menentukan bahwa "dalam hal terjadi perselisihan hasil pemilihan Kepala Desa, Bupati/Walikota wajib menyelesaikan perselisihan dalam 
jangka waktu sebagaimana dimaksud pada ayat (5)", yaitu: 30 (tiga puluh) hari sejak diterima penetapan hasil Pilkades terpilih. Berdasarkan 2 (dua) ketentuan dalam Undang-Undang Nomor 6 Tahun 2014, yaitu Pasal 31 ayat (2) dan Pasal 37 ayat (6), seharusnya Daerah Kabupaten/Kota dapat mengatur lebih teknis, operasional, dan sistematis (Maria Farida Indrati, 2007) terhadap penyelesaian perselisihan hasil pemilihan kepala desa, tidak sekedar pengulangan materi muatan atau norma yang sudah diatur dalam Undang-Undang tentang Desa dan peraturan pelaksanaannya baik dalam Peraturan Pemerintah maupun Permendagri.

Undang-Undang Nomor 6 Tahun 2014, Pasal 37 ayat (5) dan ayat (6) menentukan 2 (dua) batasan apabila terjadi perselisihan hasil pemilihan kepala desa, yaitu: pertama, pejabat yang berkewajiban atau berwenang menyelesaian perselisihan adalah bupati/walikota; dan kedua, waktu yang tersedia untuk menyelesaikan paling lama 30 (tiga puluh) hari. Peraturan di tingkat Daerah seharusnya mengatur bagaimana melengkapi ketentuan yang belum diatur oleh peraturan di atasnya terutama yang terkait dengan tahapan, mekanisme dan prosedur penyelesaiannya, bila perlu menyediakan instrumennya juga apabila terjadi pelanggaran proses pelaksanaan pemilihan kepala desa. Hal ini bisa dilakukan karena perintah untuk pembentukan peraturan daerah diberikan langsung sebagai kewenangan atribusi (Attamimi, A. Hamid S., 1990) oleh Undang-Undang Nomor 6 Tahun 2014 dalam pelaksanaan pemilihan Kepala Desa.

Penetapan calon Kades terpilih untuk sampai pada meja bupati/walikota agar dapat diselesaikan perselisihan hasil pemilihan kepala desa, maka tahap awal penetapan calon Kades terpilih oleh panitia pemilihan tingkat desa, selain disampaikan kepada BPD, juga perlu disampaikan (tembusannya) kepada calon (para calon) kepala desa lainnya yang tidak terpilih. Hal ini dimaksudkan untuk memberikan kesempatan kepada calon (para calon) kepala desa lainnya yang tidak terpilih jika ingin mengajukan keberatan kepada bupati/walikota, karena ada batas waktu kedaluwarsa pengajuan permohonan dan ini sekaligus sebagai bentuk keterbukaan apa yang dilakukan oleh panitia pemilihan kepala desa, seperti halnya ditentukan Pasal 54 ayat (3) Peraturan Bupati Malang No. 21 Th. 2018, batas waktu paling lama 3 (tiga) hari setelah penetapan hasil penghitungan suara, calon kepala desa yang keberatan dapat mengajukan permohonan perselisihan hasil Pilkades.

Pasal 44 Permendagri No. 112 Th. 2014 pada tahap penetapan hanya menentukan mekanisme laporan Panitia Pilkades ke BPD, kemudian oleh BPD dilaporkan kepada bupati atau walikota, dan terakhir bupati atau walikota mengesahkan dan mengangkat kepala desa terpilih.

Pasal 44 Permendagri No. 112 Th. 2014 tidak menyebutkan adanya kewajiban menyampaikan berita acara atau penetapan hasil perhitungan suara kepada calon (para calon) kepala desa, maka dalam pelaksanaannya di lapangan kadang calon yang kalah tidak mengetahui secara formal siapa pemenangnya (yang memperoleh suara terbanyak) dan kapan hal tersebut ditetapkan oleh panitia pemilihan sebagai dasar bagi pasangan calon yang kalah (tidak menang) untuk mengajukan keberatan. Walaupun dalam Pasal 41 ayat (6) Peraturan Menteri Dalam Negeri Nomor 112 Tahun 2014 dinyatakan bahwa Panitia Pemilihan memberikan salinan Berita Acara hasil penghitungan suara kepada masingmasing saksi calon yang hadir sebanyak 1 (satu) eksemplar dan menempelkan 1 (satu) eksemplar sertifikat hasil penghitungan suara di tempat umum. Saksi calon harus menyerahkan surat penugasan dari calon Kades kepada Panitia Pilkades, ketentun ini juga terdapat pada Pasal 51 Perbup Malang No. 5 Th. 2019.

Bupati/walikota dibatasi waktu 30 (tiga puluh) hari, maka harus dihitung secara cermat pembagian waktu mulai batas waktu pengajuan/permohonan keberatan, pemeriksaan surat dan berkas permohonan, batas waktu perbaikan surat permo- 


\section{Jurnal Cakrawala Hukum, Volume 10 No. 2 Desember 2019}

ISSN PRINT 2356-4962 ISSN ONLINE 2598-6538

honan oleh pemohon, alokasi waktu untuk pemeriksaan/klarifikasi keberatan bila perlu dengan data atau bukti-bukti pendukungnya, termasuk pemeriksaan saksi-saksi untuk menguatkan argumentasi, alokasi waktu untuk memberikan kesempatan bagi termohon serta pihak terkait, dan terakhir alokasi waktu bagi bupati/walikota beserta tim yang dibentuk (bisa berasal dari panitia pemilihan kepala desa tingkat kabupaten/kota atau bisa juga dibentuk tersendiri atau gabungan) untuk mengambil keputusan, sehingga dengan penjadwalan untuk memproses kegiatan penyelesaian perselisihan hasil pemilihan kepala desa tersebut, waktu yang tersedia 30 (tiga puluh) hari dapat diselesaikan tepat waktu.

Apabila merujuk pada Undang-Undang Nomor 10 Tahun 2016 tentang Perubahan Kedua Atas Undang-Undang Nomor 1 Tahun 2015 tentang Penetapan Perpu Nomor 1 Tahun 2015 tentang Pemilihan Gubernur, Bupati, dan Walikota Menjadi Undang-Undang, khususnya Pasal 158 yang menentukan batasan selisih suara/perbedaan perolehan suara antara calon terpilih (calon jadi) dengan calon tidak terpilih (calon tidak jadi) guna membatasi pengajuan permohonan pembatalan penetapan hasil perhitungan suara, bisa saja diatur dalam peraturan daerah terkait pengajuan keberatan terhadap hasil pemilihan kepala desa, dengan memadukan kriteria atau batasan antara jumlah penduduk desa dengan persentase selisih atau perbedaan perolehan suara, misal ditentukan selisih atau perbedaan hasil perolehan suaran antara 3 sampai $8 \%$ dari jumlah suara sah untuk dapat mengajukan keberatan.

Setelah menerima (tembusan) keputusan penetapan hasil perolehan suara yang menentukan calon kepala desa terpilih, tahap selanjutnya calon kepala desa yang tidak terpilih jika keberatan dengan penetapan hasil tersebut, dapat mengajukan permohonan perselisihan hasil kepada bupati atau walikota. Ada baiknya permohonan perselisihan hasil pemilihan kepala desa yang disampaikan kepada bupati/walikota juga ditentukan secara garis besar isi permohonan yang dimuat, misal: harus memuat identitas pemohon (nama dan alamat), sekaligus menjelaskan legal standing-nya, pihak termohon, keputusan panitia pemilian yang menjadi sebab perselisihan, menguraikan alasan menurut pemohon tentang adanya kekeliruhan atau kesalahan terhadap hasil penghitungan suara, dan terakhir menyampaikan permohonan yang diinginkan pemohon. Sebaiknya ketika pemohon menyampaikan pengajuan keberatan disertakan bukti-bukti yang mendukung pendapatnya.

Tahapan berikutnya setelah bupati/walikota menerima pengajuan atau permohonan perselisihan hasil pemilihan kepala desa, bupati/walikota beserta tim yang dibentuk mengkaji permohonan tersebut dan melakukan mediasi kepada para pihak yang berselisih agar tercapai kata sepakat. Jadi bukan menjawab (secara tertulis dan sepihak) permohonan yang diajukan oleh pihak yang keberatan. Dalam hal tidak tercapai kesepakatan antara pihak yang berselisih, selanjutnya bupati/ walikota beserta tim yang dibentuk menyelesaikan perselisihan hasil pemilihan kepala desa melalui adjudikasi sebagai decree in a cause, yaitu sebagai salah satu cara pengambilan keputusan yang diambil sesuai dengan perkara yang diperselisihkan para pihak (Henry Campbell Black, 1979).

Tahap terakhir, setelah semua pihak diberikan kesempatan untuk menyampaikan pendapat, bukti-bukti, saksi-saksi, dan didengar keterangannya, maka bupati/walikota dapat mengambil keputusan sebagai kewajibannya untuk menyelesaikan perselisihan sesuai waktu yang sudah ditentukan, yaitu 30 (tiga puluh) hari. Keputusan yang diambil bupati/walikota bisa saja dilakukan pemungutan suara ulang sebagian atau seluruhnya atau menolak keberatan pemohon dan mengukuhkan keputusan yang ditetapkan oleh panitian pemilihan kepala desa. 


\section{Simpulan}

Dengan demikian, pengaturan pemilihan kepala desa di tingkat Daerah sebagai tindak lanjut dari Undang-Undang tentang Desa dan peraturan pelaksanaannya berisi tentang kewajiban panitia pemilihan menyampaikan penetapan hasil perolehan suara yang menetapkan calon terpilih kepada calon (para calon) kepala desa, selain kepada BPD, mekanisme dan prosedur pengajuan keberatan sesuai batas waktu yang ditentukan, kewajiban bupati/walikota atau tim yang dibentuk untuk mempertemukan para pihak yang berselisih, dan jika tidak terjadi kesepakatan, maka bupati/ walikota bersama tim yang dibentuk wajib menyelesaikan perselisihan hasil. Dengan adanya tahapan penyelesaian seperti itu diharapkan memperoleh kejelasan apabila terjadi perselisihan hasil pemilihan kepala desa, yang sebenarnya perselisihan ini juga menjadi bagian dari keseluruhan proses pemilihan kepala desa.

\section{Daftar pustaka}

Asshiddiqie, Jimly. 2006. Hukum Tata Negara dan Pilarpilar Demokrasi, Edisi Revisi Cetakan Pertama. Jakarta. Konstitusi Press.

Attamimi, A. Hamid S., 1990. Peranan Keputusan Presiden Republik Indonesia dalam Penyelenggaraan Pemerintahan Negara, suatu studi analisis mengenai Keputusan Presiden yang berfungsi pengaturan dalam kurun waktu pelita I - pelita IV. Disertasi. Jakarta. Universitas Indonesia.

Black, Henry Campbell. 1979. Black's Law Dictionary. Fifth Edition. Boston. West Publishing Co.

Burton, William C., 1992. Legal Thesaurus. New York. Macmillan Publishing Company.

Indrati, Maria Farida, 2007. Ilmu Perundang-undangan, jenis, fungsi, dan materi muatan. Yogyakarta. Kanisius.
Kelsen, Hans. 1973. General Theory of Law and State. New York. Russell \& Russell.

Nahuddin, Y. (2018). Akuntabilitas Keuangan Desa dan Kesejahteraan Aparatur Desa dalam Pengelolaan Keuangan Desa. Jurnal Cakrawala Hukum, 9(1), 107-116. doi:10.26905/idjch.v9i1.2111.

Nurtjahjo, Hendra, 2005. Filsafat Demokrasi. Jakarta. Pusat Studi Hukum Tata Negara, Fakultas Hukum Universitas Indonesia.

Peraturan Bupati Malang Nomor 21 Tahun 2018 tentang Pemilihan Kepala Desa sebagaimana diubah dengan Peraturan Bupati Malang Nomor 5 Tahun 2019.

Peraturan Daerah Kabupaten Malang Nomor 1 Tahun 2016 tentang Desa.

Peraturan Menteri Dalam Negeri Nomor 112 Tahun 2014 tentang Pemilihan Kepala Desa sebagaimana diubah dengan Peraturan Menteri Dalam Negeri Nomor 65 Tahun 2017.

Peraturan Pemerintah Nomor 43 Tahun 2014 tentang Peraturan Pelaksanaan Undang-Undang Nomor 6 Tahun 2014 tentang Desa sebagaimana diubah dengan Peraturan Pemerintah Nomor 47 Tahun 2015.

Tribunnews. 2019. Pengaduan Keberatan Hasil Pilkades di Malang Tak Pengaruhi Putusan Pelantikan Cakades Terpilih. Diakses pada https://jatim.tribunnews. com/2019/08/12/pengaduan-keberatan-hasilpilkades-di-malang-tak-pengaruhi-putusanpelantikan-cakades-terpilih.

Undang-Undang Nomor 1 Tahun 2015 tentang Penetapan Peraturan Pemerintah Pengganti Undang-Undang Nomor 1 Tahun 2014 tentang Pemilihan Gubernur, Bupati, dan Walikota Menjadi Undang-Undang, sebagaimana diubah dengan Undang-Undang Nomor 8 Tahun 2015 dan terakhir dengan Undang-Undang Nomor 10 Tahun 2016.

Undang-Undang Nomor 6 Tahun 2014 tentang Desa.

Undang-Undang Nomor 7 Tahun 2017 tentang Pemilihan Umum. 
